\title{
Haruyan Hantakan Ceremony of Aruh Ganal Dayak Meratus (Mistycsemiotic Study)
}

\author{
Fajarika Ramadania ${ }^{1}$, Haris Supratno ${ }^{2}$, Setya Yuwana $^{3}$, Suhartono $^{4}$, Darni $^{5}$, Udjang Pairin ${ }^{6}$ \\ \{fajarika.19016@mhs.unesa.ac.id\} \\ Universitas Negeri Surabaya, Jl Kampus Unesa Lidah Wetan Gedung CPD Surabaya
}

\begin{abstract}
This research looks at mysticism in the Balian singing during the ceremony at the traditional dayak meratus Aruh Ganal in Hantakan Regency Haruyan Village. The purpose of this study is (1) to describe the language used to sing Balian at the traditional wedding dayak meratus; (2) to describe the mystic found in the Balian chant during the traditional aruch ceremony of Dayak Meratus. A stronger qualitative approach is the approach used in this analysis enhance its work on the deductive and inductive method of compilation and the work of inter phenomenal processes found by scientific reasoning. The way a descriptive analytical approach is used in this analysis. Source of data used the Balinan singing at the Meratus Aruh Ganal Traditional Dayak in this study will be when the banyang were born. The techniques used in this analysis for data collection are (i) documents, (ii) interviews and (iii) documents. Techniques of study used is descriptive qualitatively. This study concludes: (1) Pangunraun language (dayak Meratus) with its characteristics is the language used in Balian singing: (a) word equations /synonyms (Dayak Meratus pampadikan), (b) proverbs and (c) the use of the word "star and nanyu."
\end{abstract}

Keywords: Ganal Aruh Ceremony mystics semiotic,Dayac Meratus

\section{Introduction}

Traditional culture is a culture of Indonesian ethnic groups which, because of the influence of customs, history and customs, have their very own characteristics. A culture of Dayak is one of Indonesia's traditional cultures to be preserved. The space in which a culture was created, restored, restored, or even altered cannot therefore be taken away.[1], Similarly, the culture of dayak that in Dayak society is growing and evolving cannot be released from the lives of Dayak people as owners. Balian chant is a literary item its written language. Balian singing as already in dayak meratus. The pangunraun (dayak meratus native language) shown above. language language pangunraun is the language of the descendants of Dayak meratus who now have many Shift. Shift. Change. So, it is difficult to understand the words in a Balinese song. " ila daya kami iri uras anak kasanian," the example of pangunraun in bali songs that means 'because we are all art kids".

A system of information on the qualities and actions of other individuals, such as manners of association, is also available in balian chant. Manners in Balinese singing, for example, display reverence. "tuu siang lengan aku nawu iri santabeen" "With my voice 's tone, that means greeting" [2]. In oral tradition, the concept of "oral" refers to a tradition delivering with oral media. Oral tradition means that tradition is not only composed of verbal components, but rather that the tradition is delivered orally over centuries. The oral tradition consists, therefore, of a tradition which includes verbal, oral or nonverbal elements. The idea of "oral tradition" refers 
to a tradition which is historically sampled with oral media using "word of ear" from one gene to the other [3].

But beyond natural limitations) preternatural encounters the territory can still be interpreted in a reasonable manner) sensory awareness and the thought of a clear perception unity which transcends and which is beyond the scope of diversity. He explored three supernatural aspects of existence that we know. Different i.e. the region's "pan-en-henic" condition during its life Formation as a whole and one as a whole experience; Isolation, the closing of what we call the spirit or soul. Who's not born of something else (uncreated soul); and third, loss of human personality dignity and 'self' at the same time The 'self' in the essence of the uncreated spirit God.

Entity and every personality in God's essence Objective essence is totally gone or seems to be gone [4]. In [5]'s view those three sub-tribes have similar concept of religious and ceremonial equipment's, so it can be generalized as Dayak Meratus. There is a continuity of the religious concept of Dayak Meratus with prehistoric belief, i.e. the concept of worship ancestral spirits and the use of burial gifts in funerals The most ceremonial equipment's are made of leaves, wood and bamboo which are quickly destroyed, a few tools are made of metal and ceramic.

\section{Research Methods}

A qualitative approach is the type of analysis used. It is intended to follow a qualitative approach to solving problems by gathering data, evaluating and reporting findings based on the data collected in the analysis. The research category used is the content / documentation for research analysis by evaluating the data results of the interview. This kind of research study of the dayak mantra documentation is assisted by a direct delusion and a logical interpretation of meaning to yield detailed results since the data collected from interviews with speakers can be analysed easily. Personality of the objective essence is totally gone or seems to be gone.

Researchers based on the theory proposed by Sulistyowati and Ganie (2013) at [6] in deciding the physical form, type and role of the spells of the day. Sulistyowati and Ganié (2013) at [6] stipulate the physical form of Dayak Mantra: Dayak Mantra freeform and Dayak spell bound form. For styles of day spell, etc. such as (a) Kariau, (b) Kasumbi, (c) Mamang, (d) Pakasih, (e) Pambanci, (f) Pambungkam, (g) Panawar, (h) Panulak, (i) Papikat, (j) Pikaras, (k) Pirunduk, (1) Sumpah sarapah.

\section{Results and Discussion}

\subsection{Ceremony of Ganal in Dayak Meratus}

In view"s [7] according to Parsudi Suparlan, the Indonesian archipelago has an estimated population of more than 500 ethnic groups. The tribe has its own cultural and cultural pattern (Parsudi Suparlan, 2000: 3). The diversity of the tribes is evident from the seven cultural elements which each have: 1). 2). 2). System of expertise; 3). Profit organizations; 4). Profit organizations. Equipment and systems for living and technology; 5). Live eye system search; 6). The structure of religion; and 7). Art ([8]). Art. Indonesia can therefore be classified as a Nagara for many cultures. To boost privacy please request an English version of the website. 
All cultural products must be made up of meaning and symbols of the philosophical value that are deeply embedded in the principles and beliefs that have been installed in the beliefs of every member of daily Meratus ethnic group [9]. Regarding the old lessons of Aruh, used to be able to keep prosperity or the production of food Spirit was regarded as a part of how agriculture is developed Arif. In view [10]'s Radam's belief system (2001: 147) South Kalimantan hill people syncretic. In her past Dayak scheme of local faith in South Kalimantan got in touch with systems of Hindu and Islamic religion. He said he said he was. against the supranatural existence. Externally, dayaks know a lot God, nature spirit and ancestral spirit.

There is, among others, a God who has control and the intent of sustaining the various God the first man, and creator of the universe seven defensive plants named after with Suwara.-With Suwara. There's also the god of the registrar and the regulator of sustenance named Sangkavanang, Nining Bahatara (giving the authority and defining it) rice, and there are Hiyang and Datu Nini, and prophets,each.

The value system in some respects Dayaks is dynamic as well. Every tree and every one of their religions souls or ghosts have trees. It can be accompanied by this dynamism spells and mammals they utter at Aruh. Due to the social framework field huma structure and then every element of the it's valued their system. In this instance, in all systems, they believe a organism is invisible. In these supernatural beings, their beliefs some are good, and others are bad. Some are good. Whether these beings do bad, typically make people sad, then with sajen should be expected unique. Unique ceremonies normally take place blood is one factor. Usually, that was the blood of human beings is often used. No, it's not. By the 1900s, by the anoi, no use has been agreed more and no more human blood warfare between tribes. Then the blood of men buffalo, substituted by pig's blood or chicken. People from Dayak offer victims in the form of pigs all ceremonies.

\subsection{Mistics}

According to [11] in [4] provides four more features unlike James, genuine mysticism is active (1) Active and activities, not theoretical and passive, but rather a method of life organist (2) Mysticism 's intent is entirely transcendental and spiritual, and in no way connected with the added top, reset or update in the universe to another. The eyes naked. Mystical people's souls always in love with the one the unchanging one. (3) Intervention beyond all the one true truth something, a vivid and intimate love estuary (4) The union with the One ... is a situation or is a situation high lifestyle or mi'raj (enhanced life) walked through. He added that these four characteristics have sensible implications that real mystique encounters are never autonomous underhill illustrates supernatural encounters incorporated into (self-seeking). One is an active and continuous operation, instead of flowing sudden realization of truth abundance.

Anthropologists expose practices of edicts, which are very simple and sacred, generally known as religions, that would otherwise lead to food supplies failing. People realize that a force beyond the limits of human force knows the power, the magic power, that gives rise to a holy (sacred), divine power. This is recognised as a myth by Baal and Peursen. Religion is incorporated in their lives in a society which still maintains strong tradition, and religions are performed with different ceremonies as embodiments of their culture [12].

\subsection{Semiotic}

According [13] was the semiologist who suggested the concept of semiology. For Eco, semiotics looks at everything that can be answered as a warning. Eco stresses the position of a subject who answers something so that something is a symbol and not an object without meaning. There are two types of signs, each one with a semiotic and semiiotic sense. First there 
is a group of signs that the user actually indicated as a communication tool. This occurs if we use language to transmit information to others. It is a deliberate indication that someone says: "I'llmarket," that the system is actively communicating. Semiotics studying the use of these signs (semiosis) are referred to as semiotics for communication.

The book A Semiotics Theory is explicitly related to the theory of code generation and sign generation, with Peirce 's understanding of infinite semiosis in relation to the reader as a kind of intermediary. The Eco symbol is not just something else, it must be interpreted as well. Eco needs to prevent, on the one hand, the risk of one interpretation against the other's infinite interpretation. Nevertheless, infinite semiosis is more connected to Peirce's "interpretive" context, meaning in relation to potential circumstances. The code may typically be a morse form in which a given code (lines and points), i.e. alphabetical letters, corresponds to a set of signs.

Although there are a variety of examples among these types of codes, his principal interests are language (where code = grammar, syntax, method, and parole (language practice), and his main interests are language. Sound signs or garfis are meaningless, without code, and do not function linguistically in the most radical sense. For objects considered actual the sense of "media of signs" (e.g. words or Iamji). In other words, 'referral errors' must be avoided here Pierce in view's [14]. There is a background in the code. The social and cultural life is this background.

Thus, "cultural units are an important symbol that our social life has given us: the imaginary books for interpreters and the right answers to the two questions, the word for interpretation of meanings and vice versa. The other side of code-forming theory is the theory of symbol-building. According to [13], typological elements of how signs are formed are: 1 . Physical work: effort to make a difference. 2. Introduction: an entity or occurrence is considered to be the representation of a sign material, as a sign, symptom or evidence. 3. Evolution: an object or action becomes an example of an object or a form of action. 4. Replica: in theory tending to the difficultlis ratio, thus codifying by crawling .. E.g. musical notes, mathematical signs, etc. 5. Discovery: the most obvious difficultlis ratio scenario.

\subsection{Proverbs are used}

There are also phrases in balian singing that use slogans. Proverbs are used for a specific reason to sell something. The phrases with proverbs are here.

(1) Lagi nyantabeen ima kawan kansing la baju tepu.

'Salam hormat kepada kancing baju yang patah'.

The first song of the female number includes the sentence (1). The term kansing la baju tери (broken shirt button) is not a shirt-button, it's a proverb that is directed at the spirits and the individuals that are dead, since people who are dead have no shirts in the perception of Dayak Meratus. His mysticism cannot be seen by someone who can become a kid and who has been spirits through his ancestors. A person who becomes a baby shouldn't behave rudely and can't do something balian when a honeycomb is finished.

(3) Ikuhana ma putut gunung nanyu, ituntaka ma watu rajang lungai,

'Memohon kepada puncak gunung, memohon kepada batu rajang'.

The sentence is found in the male number's third song (2). Speaking to the bride's parents are the phrases of putut gunung nanyu and watu rajang lungai (batu rajang) since parents of the bride give birth, care and raise up the wife to make the blessing of blessing from them important. The top of the mountain is thus comparable to the bride's parents who have the 
highest rights for her child. An Balian would not be able to communicate with his ancestors who have become ghosts if he commits a bad deed or commits adultery. A child might be named a child when the local residents or dayak meratus people have or may already treat him nonmedically.

As a someone who wants to see Aruh Ganal's ritual. Organized by Dayak Meratus, we should not leave the same day prior to the event because it is considered a sacred event, so if it is left behind, we're going to get a catastrophe from the ancestors who take it for granted when someone leaves the site.

\section{5 "Star and Nanyu" Term use}

When the woman sings balian, the word used is star. The word star reveals that the baby is a female chanter. But if you want to be male, the word used is nanyu. The word nanyu shows that the singer is a man.

\section{(1) Lantunan nyanyian balian perempuan: erang hila aku bintang manyiangan lengan. \\ 'Ijinkanlah saya sebentar menyenandungkan suara'. \\ (2) Lantunan nyanyian balian perempuan: erang hila aku nanyu manyiangan lengan. \\ 'Ijinkanlah saya sebentar menyenandungkan suara'.}

The above three features of Balinese singing are very much intrinsic. This shows that there is a particular skill to compose the Balinese singing Pangunraun's words so a lovely and interesting song is made. Balian is the source of public faith and a spiritual resource. That's why, by Balinese faith and not Kaharingan, you call it your religion or belief. Balian became an intermediate of the unseen, kea lam, unknown to mankind, gave a dish to Bahatara, the $\mathrm{Pa}$ fund which he said, when he was in a state of "batandik" was the voice of the unseen.

\section{Benuang tumbu ba jurang \\ Bengkala tumbu ba napu \\ Tumpuan naan ba ulutn \\ Sangga naan ba aku \\ Artinya : \\ Benuang tumbuh dijurang \\ Bengkala tumbuh dipantai \\ Tumpuan ada diorang \\ Penyembuhan ada diaku}

Therapy Mantra/ Belian Tumpuan

The Panawar Concentration is through the Balian of sesajen and instruments and materials for example, incense, candy and pecans. Mamang talks of the mantra burning incense, frankincense and pecans over and over. Phase with the patient as the spell and the pecan are recited. The patient's scent is inhaled and added as the body is tormented traditional songs and dances are accompanied. Those who are dancing Reringgitan decorations. The course of treatment is completed from 20:00-05:00 in the morning. The purchase ceremony is held the person's home with the disease affected. Focus spell has the purpose of eliminating inflammation of the members the swelling body that's ill. Since recovering the limbs swelling is going back to its original condition. The purpose is to ask for the mantra. The Lord of Hosts, healing who has all, begging the sick person's rehab.

The term "Haruyan" in the village, for treating people with "focussed," tumpuan, pulukng, juata, ngolo utok, anak pea soyar, or pekiek korik among children, adults and the elderly is used in treatment for the disease panawar / belian. Mamang or speaker mantras use the language of 
Maratus dayak. Some daytime languages of Meratus are understandable, some unintelligible because in ancient times they used Dayac Meratus. The treatment is performed in the sick 's home because many individuals, such as a huge event, typically do the purchasing ceremony. The event is led by the motherfucker who treats the patient.

The guest will participate during the day in planning the purchasing ceremony, for example to cook, prepare equipment and buying ingredients. The purchasing ceremony will take place on the evening of 20.00-05.00 Wita. The first is the paduduk, the second is the jombu shell and the third is the puja. Three is presented here. The first step is the sit-down bar.

This is the initial rehearsal with the traditional Dayac Meratus dances and songs, performed with those who dance around reringgitan ornaments during their buying ceremony. The second process is the jombu shell, which is to compose the sesajen and the process resources. The third phase is puja, puja is a mantra reading from maman, the phase of treatments or purchases. The pronunciation of mantras usually varies between focal diseases, tumpuan, pulukng, juata, ngolo utok, anak pea soyar, or pekiek korik, but is the same process as living incense and frankincense.

\section{Conclusion}

a. This study concludes: (1) Pangunraun language (Dayac Meratus) with its charakteristics is the language used in bali singing: (a) word equations /synonyms (Dayac Meratus pampadikan), (b) proverbs and (c) the use of the word "star and nanyu". The language used in singing is the study of the researchers the pangunraun language is Balian. The Dayak Meratus language is Pangunraun used in ancient times by their forefathers. Language Pangunraun is which is very subtle and now has many interactions, as opposed to the dayak meratus language shift change.

b. Balian by the culture of Meratus in South Kalimantan shows how the treatment/ balian mantra works healing, removing, or treating the pain of both children, animal illness, the fragile and the invisible beings, the adults and the elderly, even the man's own job. The aim of the mantra is to request healing all-powerful, for it is lifted and healed by his permission. The mechanism is directly referred to as a balian well. Following is the mechanism sunset or evening with 20:00 set time about 5:00 a.m. Trust it because you think that the best method is at night treatment when it's time to work during the day. Phase treatment takes place in a sick person's home, as the balanced ceremony is usually carried out many enjoy great activities. The ceremony in Balian includes not only symbolic patterns, but also a social interaction type. The ritual also helps to preserve unity and regularity Meratus society's social life.

\section{References}

[1] I. Abdullah, Konstruksi dan Reproduksi Kebudayaan. Yogyakarta: Pustaka Pelajar, 2010.

[2] J. Bahasa et al., "Nilai Budaya dalam Nyanyian Balian pada Upacara Perkawinan Adat Dayak Maratus di Kabupaten Hulu Sungai Tengah," vol. 4, no. 1, pp. 1-15, 2019.

[3] R. Sibarani, "Pendekatan Antropolinguistik Terhadap Kajian Tradisi Lisan,” RETORIKA J. Ilmu Bhs., vol. 1, no. 1, p. 1, 2015, doi: 10.22225/jr.v1i1.9.

[4] S. Zarrabizadeh, "Mendefinisikan Mistisisme: Sebuah Tinjauan atas Beberapa Definisi Utama," Kanz Philos. A J. Islam. Philos. Mysticism, vol. 1, no. 1, p. 93, 2011, doi: 10.20871/kpjipm.v1i1.7.

[5] M. D. I. Kotabaru and K. Selatan, "Religi Dan Peralatan Tradisional Suku Dayak," pp. 95-120, 2015. 
[6] F. Ramadania, "Kajian Semiotika Mantra Banjar,” J. Tarb. J. Ilm. Kependidikan, vol. 7, no. 1, pp. 51-57, 2018, doi: 10.18592/tarbiyah.v7i1.2101.

[7] R. B. Pratama and A. Nurcahyo, "Kajian Sosioreligi Nilai-Nilai Upacara Aruh Baharin Dalam Masyarakat Dayak Meratus Halong Kabupaten Balangan Sebagai Sumber Pembelajaran Nilai Berbasis Multikultural,” Agastya J. Sej. Dan Pembelajarannya, vol. 9, no. 1, p. 94, 2019, doi: 10.25273/ajsp.v9i1.3640.

[8] Koentjaraningrat, Pengantar Ilmu Antropologi. Jakarta: PT. Renika Cipta, 2010.

[9] M. Anshari, "Basambur Healing Rituals on Etnomedicine of Dayak Paramasan Meratus : Collective Mindset Effect on Perception Response ( Ritual Penyembuhan Basambur Pada Etnomedisin Dayak Paramasan Meratus : Pengaruh Mindset Kolektif Terhadap Respons Persepsi ),”vol. 2, no. 1, pp. 20 25, 2018.

[10] M. Soehadha, "Islam, Kristen, dan Aruh: Agama Baru dan Perubahan Agroekosistem Peladang Dayak Loksado, Kalimantan,” JSW J. Sosiol. Walisongo, vol. 2, no. 1, p. 83, 2018, doi: 10.21580/jsw.2018.2.1.2481

[11] E. Underhyll, Mysticism: the Nature and Development of Spiritual Consciousness. Oxford: Oneworld, 1994.

[12] J. J. Daeng, Manusia, Kebudayaan, dan Lingkungan: Tinjauan Antropologis. Yogyakarta: Pustaka Pelajar, 2000.

[13] U. Eco, Teori Semiotika, Signifikasi Komunikasi, Teori Kode, Setra Teori Produksi-Tanda (Terjemahan Insiak Ridwan Munsir). Bantul: Kreasi Wacana Offset, 2016.

[14] A. J. Ramadania, Fajarika, Pengantar Semiotika ( Tanda-Tanda dalam Kebudayaan Lokal) Buku Ajar. Banjarbaru: Zukzez Express, 2018. 